\begin{tabular}{|c|c|c|}
\hline & Int.J.Curr.Microbiol.App.Sci (2021) 10(12): 509-520 & \\
\hline & $\begin{array}{l}\text { International Journal of Current Microbiology and Applied Sciences } \\
\text { ISSN: 2319-7706 Volume } \mathbf{1 0} \text { Number } \mathbf{1 2} \mathbf{( 2 0 2 1 )} \\
\text { Journal homepage: } \underline{\text { http://www.ijcmas.com }}\end{array}$ & 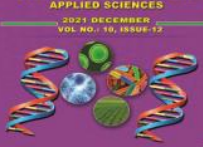 \\
\hline $\begin{array}{l}\text { EXCELLENT } \\
\text { PUBLISHERS }\end{array}$ & & \\
\hline
\end{tabular}

\title{
Analytical Study of the Value Chains of Garlic Crop and the Role of Agricultural Manufacturing in Beni Suef Governorate, Egypt
}

\author{
Mohamed Hussien Mohamed Attwa ${ }^{1 *}$, Hussien Mohamed Ahmed Hussien ${ }^{1}$, \\ Mohamed Desouki Hassan Dewdar ${ }^{2}$ and Ghada Abd El Samee Rabee Mansour Ghedan ${ }^{1}$
}

\author{
${ }^{1}$ BeniSuef Economic Unit, Agricultural Economics Institute, Agricultural Research Center \\ ${ }^{2}$ Department of Agronomy, Fayoum University, Egypt
}

*Corresponding author

\section{Keywords}

Food commodities, Egyptian house, annual cultivated area

\section{Article Info}

Received: 12 November 2021 Accepted: 05 December 2021 Available Online: 10 December 2021

\section{A B S T R A C T}

The study mainly aims to analyze the value chains for the production, processing and marketing of the garlic crop in Beni Suef Governorate, Egypt and the most important problems and obstacles it faces in the production, manufacturing and marketing stages, and to propose solutions to them. The results show that the best pictures for marketing garlic can be arranged as follows. Exporting fasting comes in the form of mature, plasticized garlic, followed by exporting it in the form of dried garlic slices or powder, then in the form of immature garlic, and finally in the form of mature garlic, where the added value of each of them is about 28,648 pounds. 28,350 pounds, 24000 pounds, zero pounds, respectively. In the case of arranging according to the net return indicators, the total return on costs and the return on the invested pound, the export of plasticized ripe garlic comes in the first order, followed by immature garlic, then dried and then mature garlic that is marketed in the local market, where the value of the net return amounted to about 25468, 19885, 16615 and 10688 pounds, respectively. While the return on the invested pound amounted to about 2.09, 0.99, 0.53, and 0.49 for each of them, respectively. Beni Suef Governorate is considered the first in terms of area and production of garlic for the republic, where it is planted about $36.4 \%$, and produces about $40.4 \%$ of the production of the republic and the average costs of production per fed. amounted to about 21.712 pounds, the percentage of fixed costs in it about $30.2 \%$, while variable costs represent about $69.8 \%$. Rent comes in the first order of fixed costs, representing about $29.5 \%$ of the total costs, while labor costs in all stages of production come at the forefront of the arrangement of variable costs and represent about $19.7 \%$, followed by the costs of chemical fertilizers, which represent about $13.9 \%$ of the total costs. 


\section{Introduction}

Garlic is one of the important food commodities, almost in an Egyptian house, where it is used in preparing most Egyptian foods since the time of the Pharaohs. Minerals necessary for the body, China is the largest producer of it, followed by India, South Korea and Egypt in fourth place (FAO). Beni Suef is considered one of the main governorates in garlic production in Egypt. Where the average annual cultivated area reached about 10327 acres, representing about $36.4 \%$ of the area of the Republic, producing about 106807 tons, representing about $40.4 \%$ of the average total production of the Republic during the period from 2004 to 2017.

It should also be noted that Egyptian garlic has two comparative advantages compared to global garlic, which is that it is presented in the global market before garlic that is produced from competing countries such as Spain, Morocco, China and India, as it ripens before the garlic grown in these countries. High global marketing, especially the distinctive taste and flavor, which makes it a distinctive product that is required globally.

Despite the increase in the quantity produced from the garlic crop in Egypt in general and Beni Suef in particular, a very limited proportion of it is directed to manufacturing for the purpose of drying, and another quantity is directed to export according to the conditions of global demand for garlic, and the rest is directed to local consumption. The value chain is considered one of the activities analysis tools that work on segmenting and analyzing the main and interrelated activities within the farm or establishment in order to focus on the activities that increase the value of the product in the form of revenues or profits. The value chain of the garlic crop includes a group of activities that are interrelated with each other, starting from the garlic production cycle in the farm, passing through the marketing and manufacturing cycles until it reaches the final consumer.

\section{The study Problem}

Beni Suef governorate is one of the distinguished governorates among the governorates of the Republic in the production, manufacture and marketing of the garlic crop - it grows about $36.4 \%$ of the garlic area at the level of the Republic, and there are a number of factories that dry garlic and export it in the form of slices or powder, while it is also available A number of export companies are exporting garlic in various forms. However, there is no correlation between garlic farmers, factory owners and export companies, which results in severe fluctuations in garlic production and prices from year to year. Therefore, the study was interested in identifying the problems, obstacles, and determinants of garlic growth and development, and attention to manufacturing processes and competition with it externally, especially with the countries of the European Union. The study mainly aims to analyze the value chains for the production, processing and marketing of the garlic crop in Beni Suef Governorate, and the most important problems and obstacles it faces in the production, manufacturing and marketing stages, and to propose solutions to them.

\section{Materials and Methods}

To achieve the objectives of the study, both descriptive and quantitative statistical analysis methods were used. The study relied on published and unpublished secondary data for the variables under study issued by the concerned official authorities. Two questionnaire forms were designed, one for the production of garlic, and the other for factories and garlic export companies, and some research was used. and previous studies 
related to the subject of the study, The data was collected through three sources: the first source is the data of the Ministry of Agriculture and Land Reclamation, the Economic Affairs Sector, the Directorate of Agriculture in Beni Suef Governorate, the Investment Authority of the General Court of Beni Suef Governorate, and studies and research closely related to the subject of the study in order to obtain the published and unpublished secondary data for Time series, factories and export companies working in the field of study.

The second source is the garlic production community themselves, and due to the difficulty of conducting this study on all the vocabulary of the study community, the sample method was relied on to study the original community with good investigation so that this sample was a true representation of it, as the farmer was considered the first sample unit for research next to the factories Which works in the field of drying as well as export companies in Beni Suef Governorate.

Three administrative centers representing the governorate were selected, which are AlWasta Center, Nasser Center, and Ihnasia Center (Table 1) as the largest centers that cultivate garlic in the governorate.

The third source is the community of factory owners and export companies located in Beni Suef Governorate in both the industrial zone of Bayyad Al Arab (Healthy Foods Factory, Al Shorouk Factory, Upper Egypt Food Industry Company, Hydrofoods Factory, Beni Suef Factory) and the light industries area in the new city of Beni Suef (Factory AlShennawy, Taiba Factory), Kom Abu Radi Industrial Area (Agricultural Development Company in Upper Egypt), and in the village of Tansa Al-Malaq, Nasser Center (Export Stars Company, Al-Israa Company for Import and Export of Agricultural Crops).
A study by Siyam (2019) showed that the modest economic performance of the vegetable sector in Egypt is the final outcome of a number of problems and restrictions facing the value chains of vegetable crops in their various stages, foremost among which are the weakness of the varieties, the randomness of the varietal composition, and the predominance of the use of traditional agricultural methods in production. Marketing, the severity of price fluctuations, and the unfair distribution of benefits in value chains.

In the study El-Gendy et al., (2019) on an economic study to analyze the value chain and marketing windows for the export of potatoes to the Russian Federation, the study concluded the need to expand the production of the potato crop to ensure an increase in the exported quantity, as well as the need to provide production requirements to farmers at the appropriate time and price and work to raise the marketing efficiency of potatoes, The necessity of raising the globally required marketing qualities for potatoes, and providing the necessary database for workers in the chain of production, marketing, manufacturing and exporting potatoes.

In their study by Yasin et al., (2019) indicated an analytical study of losses in some stages of the value chain of the tomato crop. The most important causes of losses at the level of wholesale markets were the failure to sort out the defective fruits from the farm, and the use of leaflet cages for packing.

In the study by Mahjoub (2016), on the analysis of benefits and costs for field crops in Sharkia Governorate, the study indicated the need to reduce the high production costs of important strategic crops, including garlic, by supporting production requirements (seeds, fertilizers, pesticides) and providing them in a timely manner through cooperative societies, with Expansion of the automated service to achieve a return that encourages farmers to 
expand the cultivation of these crops, and the study recommended the necessity of conducting specialized studies in calculating the flows according to variable discount rates as in commercial banks.

In the study by Wafaa (2011) the results showed a decrease in the rate of penetration into the markets of the most important importing countries of Egyptian garlic during the two study periods, which indicates the weak possibility of penetration of Egyptian garlic to those countries, which means that Egypt does not have a competitive advantage in these markets, while we find a relative increase of this indicator in the markets of all countries. From the Republic of South Africa, then Mauritius, or Lebanon.
Elias 2002, study on the marketing of garlic in Egypt and the impact of post-harvest transactions, and the results of the study concluded that the Egyptian production of garlic exceeds the need for local consumption as food and other uses, and then there is a surplus in the current production of more than $30 \%$ that can be directed to export by following Appropriate export policies, especially since export prices are much more rewarding than marketing garlic in the local market, and the study recommended taking into account early planting dates and not delaying them until mid-September, especially for those to be exported so that they can benefit from the early production until February and March when foreign markets are free of garlic Which begins in early April.

Table.1 Distribution of the study sample items for the garlic crop on the selected centers and villages.

\begin{tabular}{|c|c|c|c|c|}
\hline $\begin{array}{c}\text { Number of farmers in } \\
\text { the sample }\end{array}$ & $\mathbf{\%}$ & $\begin{array}{c}\text { The area of } \\
\text { garlic in fed }\end{array}$ & Village & Center \\
\hline $\mathbf{2 0}$ & 63 & 933 & Abusir Al-Malq & Wasta \\
\cline { 3 - 4 } $\mathbf{1 1}$ & 37 & 538 & Qimn the bride & \\
\hline $\mathbf{3 1}$ & 44 & 1471 & 2 & Total Wasti Center \\
\hline $\mathbf{1 8}$ & 68 & 862 & Tanga El Malak & Naser \\
\hline $\mathbf{9}$ & 32 & 415 & Behbeshin & \\
\hline $\mathbf{2 7}$ & 39 & 1277 & 2 & Total Nasser Center \\
\hline $\mathbf{7}$ & 60 & 339 & S. Elgabal & Ehnasia \\
\hline $\mathbf{5}$ & 40 & 230 & M.El-emra & \\
\hline $\mathbf{1 2}$ & 17 & 569 & 2 & Total Ehnasia Center \\
\hline $\mathbf{7 0}$ & 100 & 3317 & 6 & Total study sample \\
\hline
\end{tabular}

Source: Directorate of Agriculture in Beni Suef, Information Center.

\section{Results and Discussion}

The current situation of the area and production of garlic at the level of the Republic and Beni Suef:

Table (2) indicates that Beni Suef governorate ranks first among the governorates of the Republic the area of garlic cultivation. Its relative importance during period 2004/2017 ranged between a minimum of about $32.1 \%$ in 2008 , and a maximum of about $51.8 \%$ in 2015 , with average about $36.4 \%$ of the average garlic cultivation area at the level of the Republic. The study showed the relative importance of the production of Beni Suef Governorate compared to the production of the Republic Table (2), that it ranged between 
$33.1 \%$ and $56.4 \%$ in 2015 , with an average $40.4 \%$ of production of garlic during the study period.

The development of garlic cultivation area in Beni Suef and Republic during 2004: 2017

The results in Table (3) showed that the area of garlic in Egypt takes semi-increasing and then decreasing waves every two or three years. Farmers stop planting it when its price drops. Its shows that the area planted with garlic reached maximum in 2008, reaching about 126\% compared 2004, and reached minimum in 2009. The results also showed that the area planted with garlic in Beni Suef takes the same characteristics of the cultivated area of the Republic and it reached its maximum in 2016 where it reached about $130 \%$ compared to the base year 2004, It reached its lowest level in 2009 , reaching $76 \%$ compared to the base year.

Development of garlic production at the level of Republic and Beni Suef during 2004: 2017

Data in Table (4) showed that the garlic production of the Republic was fluctuated during the study period, and it reached maximum in 2008, when it reached $119 \%$ compared to the base year 2004, while it reached its minimum in 2009, where it reached about $69 \%$ compared to the base year. While Beni Suef Governorate, the of production reached its highest in 2008, reaching about $137 \%$ compared to the base year, and reached minimum in 2006, reaching $80 \%$. Analysis of the actors in the value chain of garlic production, processing and marketing in Beni Suef Governorate:

The stage of the value chains for the production, processing and marketing of garlic includes important stages, the pre-agricultural stage, in which the percentage of those cultivating less than an fed was about $38.6 \%$, while the percentage of those cultivating an fed of 1 acre was about $50 \%$, and the percentage of those cultivating more than an fed. About $11.4 \%, 65.8 \%$ of the farmers also made the decision to plant because garlic gives a good return, as well as because of the spread of its cultivation in the region, while $34 \%$ believe that they grow it because it is an easy-to-market crop, while the majority of farmers consider the neighboring farmers as the main source of their knowledge garlic cultivation about $82.9 \%$, while friends represent about $10 \%$, while the role of agricultural extension represented about $4.3 \%$, and manufacturing and export companies represented only $2.9 \%$. Relatively, also the experience of garlic growers in Beni Suef is due to the fact that garlic is grown in Beni Suef continuously and from long periods, where the percentage of those who grow garlic from 5 to 10 years is about $48.6 \%$, and the percentage of those who grow it from 10 to 20 years is about $25.7 \%$, while The percentage of those who have been cultivating garlic for more than 20 years represents about $14.3 \%$, (Tables 5 and 6 ). The stage of cultivation, where the results of the study showed that although about $87.1 \%$ of farmers adopt technical recommendations, they adopt them in varying proportions in terms of quantity and quality, and that there are important and influential recommendations in the quantity and quality of production that they adopt in a small percentage, for example, despite the great impact of the cultivar and the quality of the seeds, but only $40 \%$ of the farmers are keen on this matter.

The study showed that most farmers were not aware of modern technical recommendations in the pre-harvest stage of garlic, especially potassium fertilization before the end of the season, as well as stopping irrigation and fasting garlic at least two weeks before harvest - factors that greatly affect the quantity of production and the quality of its marketing 
qualities, as their percentage reached about $44.3 \%$ and $28.6 \%$, respectively. Also among the prominent characteristics at this stage is that farmers get modern recommendations from neighboring farmers, friends and relatives in the first place, where the percentage of those who get acquainted with the modern recommendations of them is about 36.4 and $35.5 \%$, respectively, while the percentage of those who get modern technical recommendations from the guidance The agricultural sector is only about $26.4 \%$. The study also showed $40 \%$ of the farmers encountering a problem in obtaining good seeds, as the study showed that $85.6 \%$ suffer from the high price of seeds, and about $75 \%$ suffer from the lack of good seeds, (Tables 7 and 8).

The results of the study showed that about $56.4 \%$ of farmers prefer to sell their crops themselves in garlic sales rings, compared to $40.6 \%$ who sell their crop standing in the field (totally) to traders, $2 \%$ to exporters, and $1 \%$ to garlic drying factories. The results of the study showed that the percentage of companies buying from the farm gate represents only about $2 \%$ of the total sale of farmers, the results of the study also showed that the percentage of factory owners buying garlic directly from the farmers is very weak, as it represents about $1 \%$ of the total sale of garlic farmers (Table 9).

Table.2 Economic indicators of garlic crop in Egypt and Beni Suef Governorate during 2004 to 2017

\begin{tabular}{|c|c|c|c|c|c|c|}
\hline \multicolumn{3}{|c|}{ Production (ton) } & \multicolumn{3}{c|}{ Area in (Fed.) } & \multirow{2}{*}{ Year } \\
$\begin{array}{c}\text { Relative } \\
\text { importance }\end{array}$ & Beni Suef & Egypt & $\begin{array}{c}\text { Relative } \\
\text { importance }\end{array}$ & Beni Suef & Egypt & \\
\hline $\mathbf{3 3 . 1}$ & 94375 & 285294 & 32.8 & 9869 & 30115 & 2004 \\
\hline $\mathbf{3 6 . 1}$ & 87555 & 242485 & 34.5 & 8975 & 26028 & 2005 \\
\hline $\mathbf{3 4 . 8}$ & 75494 & 217197 & 32.3 & 7555 & 23411 & 2006 \\
\hline $\mathbf{3 9 . 5}$ & 121951 & 308806 & 35.3 & 11624 & 32944 & 2007 \\
\hline $\mathbf{3 7 . 9}$ & 128845 & 339621 & 32.1 & 12164 & 37845 & 2008 \\
\hline $\mathbf{4 2 . 4}$ & 83061 & 195741 & 37.1 & 7522 & 20256 & 2009 \\
\hline $\mathbf{4 3 . 6}$ & 106614 & 244620 & 38.2 & 10005 & 26218 & 2010 \\
\hline $\mathbf{4 2 . 5}$ & 125650 & 295833 & 35.9 & 11408 & 31787 & 2011 \\
\hline $\mathbf{3 9 . 1}$ & 120889 & 309190 & 35.0 & 11074 & 31621 & 2012 \\
\hline $\mathbf{3 9 . 5}$ & 92389 & 234163 & 33.7 & 8246 & 24469 & 2013 \\
\hline $\mathbf{3 9 . 2}$ & 103150 & 263161 & 36.6 & 10300 & 28157 & 2014 \\
\hline $\mathbf{5 6 . 4}$ & 111947 & 198598 & 51.8 & 11330 & 21875 & 1015 \\
\hline $\mathbf{4 3 . 2}$ & 117688 & 272229 & 41.0 & 12855 & 31354 & 2016 \\
\hline $\mathbf{4 3 . 4}$ & 125682 & 289766 & 36.9 & 11657 & 13570 & 2017 \\
\hline $\mathbf{4 0 . 4}$ & 106806 & 264050 & 36.4 & 10370 & 28404 & Mean \\
\hline
\end{tabular}

Source: Ministry of Agriculture and Land Reclamation - Economic Affairs Sector - Agricultural Economics Bulletin. 
Table.3 Development of the cultivated area of the garlic crop in Beni Suef Governorate and the Republic during 2004: 2017

\begin{tabular}{|c|c|c|c|c|}
\hline \multicolumn{2}{|c|}{ Beni Suef } & \multicolumn{2}{|c|}{ Egypt } & \multirow{2}{*}{ Year } \\
\hline Standard Number & Area in Fed.* & Standard Number & Area in Fed.* & \\
\hline $\mathbf{1 0 0}$ & 9869 & 100 & 30115 & $2004^{* *}$ \\
\hline $\mathbf{9 1}$ & 8975 & 86 & 26028 & 2005 \\
\hline $\mathbf{7 7}$ & 7555 & 78 & 23411 & 2006 \\
\hline $\mathbf{1 1 8}$ & 11624 & 109 & 32944 & 2007 \\
\hline $\mathbf{1 2 3}$ & 12164 & 126 & 37845 & 2008 \\
\hline $\mathbf{7 6}$ & 7522 & 67 & 20256 & 2009 \\
\hline $\mathbf{1 0 1}$ & 10005 & 87 & 26218 & 2010 \\
\hline $\mathbf{1 1 6}$ & 11408 & 106 & 31787 & 2011 \\
\hline $\mathbf{1 1 2}$ & 11074 & 105 & 31621 & 2012 \\
\hline $\mathbf{8 4}$ & 8246 & 81 & 24469 & 2013 \\
\hline $\mathbf{1 0 4}$ & 10300 & 93 & 28157 & 2014 \\
\hline $\mathbf{1 1 5}$ & 11330 & 73 & 21875 & 1015 \\
\hline $\mathbf{1 3 0}$ & 12855 & 104 & 31354 & 2016 \\
\hline
\end{tabular}

Source: Ministry of Agriculture and Land Reclamation - Economic Affairs Sector - Bulletin of Agricultural Economics.

*The area includes garlic in the old and new lands by the solid and intercropping cultivation.

** Consider 2004 as the base year.

Table.4 Development of the production of the garlic crop in Beni Suef Governorate and the Republic during 2004: 2017

\begin{tabular}{|c|c|c|c|c|}
\hline \multicolumn{2}{|c|}{ Beni Suef } & \multicolumn{2}{c|}{ Egypt } & \multirow{2}{*}{ Year } \\
\hline $\begin{array}{c}\text { Standard Number } \\
\mathbf{\%}\end{array}$ & $\begin{array}{c}\text { Production } \\
\text { in ton* }\end{array}$ & $\begin{array}{c}\text { Standard } \\
\text { Number \% }\end{array}$ & $\begin{array}{c}\text { Production } \\
\text { in ton* }\end{array}$ & \\
\hline $\mathbf{1 0 0}$ & 94375 & 100 & 285294 & $2004 * *$ \\
\hline $\mathbf{9 3}$ & 87555 & 85 & 242485 & 2005 \\
\hline $\mathbf{8 0}$ & 75494 & 76 & 217197 & 2006 \\
\hline $\mathbf{1 2 9}$ & 121951 & 108 & 308806 & 2007 \\
\hline $\mathbf{1 3 7}$ & 128845 & 119 & 339621 & 2008 \\
\hline $\mathbf{8 8}$ & 83061 & 69 & 195741 & 2009 \\
\hline $\mathbf{1 1 3}$ & 106614 & 86 & 244620 & 2010 \\
\hline $\mathbf{1 3 3}$ & 125650 & 104 & 295833 & 2011 \\
\hline $\mathbf{1 2 8}$ & 120889 & 108 & 309190 & 2012 \\
\hline $\mathbf{9 8}$ & 92389 & 82 & 234163 & 2013 \\
\hline $\mathbf{1 0 9}$ & 103150 & 92 & 263161 & 2014 \\
\hline $\mathbf{1 1 9}$ & 111947 & 70 & 198598 & 1015 \\
\hline $\mathbf{1 2 5}$ & 117688 & 95 & 272229 & 2016 \\
\hline $\mathbf{1 3 3}$ & 125682 & 102 & 289766 & 2017 \\
\hline
\end{tabular}

Source: Ministry of Agriculture and Land Reclamation - Economic Affairs Sector - Bulletin of Agricultural Economics.

*The production includes garlic in the old and new lands by the solid and intercropping cultivation.

** Consider 2004 as the base year. 
Table.5 The categories of garlic growers and the reasons for their cultivation.

\begin{tabular}{|c|c|c|c|}
\hline \multicolumn{2}{|c|}{ Reasons for growing garlic } & \multicolumn{2}{c|}{ The area planted of garlic } \\
\hline $\begin{array}{c}\text { Relative } \\
\text { frequency }\end{array}$ & The reason & $\begin{array}{c}\text { Relative } \\
\text { frequency }\end{array}$ & Classes \\
\hline $\mathbf{3 8 . 9}$ & High net income & 37.6 & Less than Fed. \\
\hline $\mathbf{3 4 . 3}$ & Easy marketing & 50 & Fed. \\
\hline $\mathbf{2 6 . 9}$ & It is widely cultivated in the region & 11.4 & More than Fed. \\
\hline $\mathbf{1 0 0}$ & Total & 100 & Total \\
\hline
\end{tabular}

Source: Collected and calculated from the questionnaire forms of the field study sample in 2019: 2020.

Table.6 The experience of garlic growers and the source of their knowledge of its cultivation.

\begin{tabular}{|c|c|c|c|}
\hline \multicolumn{2}{|c|}{ Source of farmers' knowledge garlic crop } & \multicolumn{2}{|c|}{ When did you start growing garlic? } \\
\hline Freq. $\%$ & Reason & Freq. $\%$ & Reason \\
\hline $\mathbf{8 2 . 9}$ & Neighborhood & 11.4 & Less than 5 years \\
\hline $\mathbf{4 . 3}$ & Agricultural guidance & 48.6 & From 5: 10 years \\
\hline $\mathbf{2 . 9}$ & Export companies & 25.7 & From 10 to 20 years old \\
\hline $\mathbf{1 0}$ & Friends & 14.3 & More than 20 years \\
\hline $\mathbf{1 0 0}$ & Total & 100 & Total \\
\hline
\end{tabular}

Source: Collected and calculated from the questionnaire forms of the field study sample in 2019: 2020.

Table.7 Source of farmers' access to modern technical information and recommendations.

\begin{tabular}{|c|c|}
\hline Rep.\% & Cause \\
\hline $\mathbf{3 6 . 4}$ & Neighborhood farmers \\
\hline $\mathbf{2 6 . 4}$ & Agricultural guidance \\
\hline $\mathbf{3 5 . 5}$ & Friends and Relatives \\
\hline $\mathbf{1 . 7}$ & TV \\
\hline $\mathbf{1 0 0}$ & Total \\
\hline
\end{tabular}

Source: Collected and calculated from the questionnaire forms of the field study sample in 2019: 2020.

Table.8 The problems of garlic farmers' access to good, disease-free seeds.

\begin{tabular}{|c|c|c|c|}
\hline $\begin{array}{c}\text { The problems encountered by farmers in } \\
\text { obtaining good seeds }\end{array}$ & \multicolumn{2}{|c|}{ There are problems in obtaining good seeds } \\
\hline Rep.\% & Reason & Rep. $\%$ & Reason \\
\hline $\mathbf{8 5 . 6}$ & Seed price & 40 & Yes \\
\hline $\mathbf{1 4 . 4}$ & Lack of good seeds & 60 & No \\
\hline $\mathbf{1 0 0}$ & & 100 & Total \\
\hline
\end{tabular}

Source: Collected and calculated from the questionnaire forms of the field study sample in 2019: 2020. 
Table.9 Methods of the farmers sell garlic.

\begin{tabular}{|c|c|}
\hline Rep. $\%$ & Reason \\
\hline $\mathbf{5 6 . 4}$ & local market \\
\hline $\mathbf{4 0 . 6}$ & Wholesaler \\
\hline $\mathbf{2}$ & exporters \\
\hline $\mathbf{1}$ & Factories \\
\hline $\mathbf{1 0 0}$ & Total \\
\hline
\end{tabular}

Source: Collected and calculated from the questionnaire forms of the field study sample in 2019: 2020. **The economics of garlic crop during the different stages of production and marketing

Table.10 The relative importance of the cost components of garlic production (pounds / feddan) according to the study sample for the agricultural season 2018: 2019.

\begin{tabular}{|c|c|c|c|}
\hline Total costs \% & Variable costs \% & Costs & Factors of production \\
\hline $\mathbf{2 . 3}$ & 3.4 & 510 & Plowing and planning \\
\hline $\mathbf{4 . 8}$ & 6.9 & 1041 & Irrigation machine \\
\hline $\mathbf{1 . 5}$ & 2.1 & 317 & Spray machine \\
\hline $\mathbf{9 . 4}$ & 13.5 & 2051 & Seeds \\
\hline $\mathbf{7 . 0}$ & 10.0 & 1512 & Manure fertilizer \\
\hline $\mathbf{1 3 . 9}$ & 20.0 & 3026 & Chemical fertilizers \\
\hline $\mathbf{6 . 3}$ & 9.0 & 1364 & Pesticides and fertilizers \\
\hline $\mathbf{1 9 . 7}$ & 28.2 & 4282 & Workers \\
\hline $\mathbf{3 . 8}$ & 5.4 & 816 & Transport and weight \\
\hline $\mathbf{1 . 1}$ & 1.6 & 243 & Petty cash \\
\hline $\mathbf{6 9 . 8}$ & 100 & 15162 & Total variable costs \\
\hline $\mathbf{2 9 . 5}$ & - & 6400 & Fixed costs (rent) \\
\hline $\mathbf{0 . 7}$ & - & 150 & Taxes \\
\hline $\mathbf{3 0 . 2}$ & - & 6550 & Total fixed costs \\
\hline $\mathbf{1 0 0}$ & - & 21712 & Total costs \\
\hline
\end{tabular}

Source: Collected and calculated from the questionnaire forms of the field study sample in 2019: 2020. 
Table.11 Costs of producing a ton of dried garlic in the Egyptian pound in 2018: 2019.

\begin{tabular}{|c|c|c|c|}
\hline Total costs \% & $\begin{array}{c}\text { Fixed and variable } \\
\text { costs } \%\end{array}$ & Value of costs & Production component \\
\hline- & - & & Fixed costs \\
\hline 9.6 & 55.4 & 3000 & Workers \\
\hline 1.6 & 9.2 & 500 & $\begin{array}{c}\text { Destruction of machinery and } \\
\text { equipment }\end{array}$ \\
\hline 1.3 & 7.4 & 400 & $\begin{array}{c}\text { Maintenance of machines and } \\
\text { equipment }\end{array}$ \\
\hline 1.4 & 8.3 & 450 & $\begin{array}{l}\text { Rental of machinery and } \\
\text { equipment }\end{array}$ \\
\hline 0.2 & 0.9 & 50 & Taxes \\
\hline 0.2 & 1.0 & 55 & Insurances \\
\hline 0.8 & 4.6 & 250 & Administrative expenses \\
\hline 0.7 & 3.9 & 210 & Training courses \\
\hline 1.6 & 9.2 & 500 & $\begin{array}{l}\text { Quality improvement } \\
\text { expenses }\end{array}$ \\
\hline 13.7 & 100 & 5415 & Total fixed costs \\
\hline- & - & & Variable costs: \\
\hline 62.6 & 75.7 & 19650 & $\begin{array}{c}\text { Raw Materials (4 Tons Dry } \\
\text { Plasticized Garlic) }\end{array}$ \\
\hline 12.3 & 14.9 & 3860 & Natural gas \\
\hline 3.1 & 3.8 & 980 & Electricity \\
\hline 2.9 & 3.5 & 920 & Waters \\
\hline 1.0 & 1.2 & 395 & Packing and warping material \\
\hline 0.8 & 1.0 & 255 & Shipping freight \\
\hline 82.7 & 100 & 25970 & Total variable costs \\
\hline 100 & - & 31385 & Total costs \\
\hline- & - & 48000 & Ton value \\
\hline
\end{tabular}

Source: Collected and calculated from the questionnaire forms of the field study sample in 2019: 2020 .

*Economic indicators of garlic production, processing and marketing

Table.12 Important economic indicators for the production, processing and marketing of garlic.

\begin{tabular}{|c|c|c|c|c|}
\hline $\begin{array}{c}\text { Dehydrated } \\
\text { garlic slices and } \\
\text { powder export } \\
\text { (tons) }\end{array}$ & $\begin{array}{c}\text { Plasticized } \\
\text { ripe garlic } \\
\text { Export (tons) }\end{array}$ & $\begin{array}{c}\text { Unripe garlic } \\
\text { export (tons) }\end{array}$ & $\begin{array}{c}\text { Fresh garlic } \\
\text { local sale*** } \\
\text { (fed.) }\end{array}$ & $\begin{array}{c}\text { The product } \\
\text { Indicator }\end{array}$ \\
\hline $\mathbf{3 1 3 8 5}$ & 12180 & 20115 & 21712 & Total costs \\
\hline $\mathbf{4 8 0 0 0}$ & 37648 & 40000 & 32400 & Total return \\
\hline $\mathbf{1 6 6 1 5}$ & 25468 & 19885 & 10688 & Net return \\
\hline $\mathbf{1 . 5 3}$ & 3.09 & 1.99 & 1.49 & Total cost return \\
\hline $\mathbf{0 . 5 3}$ & 2.09 & 0.99 & 0.49 & $\begin{array}{c}\text { Return on the invested } \\
\text { pound }\end{array}$ \\
\hline & 28648 & 24000 & - & Total value added \\
\hline $\mathbf{2 8 3 5 0}$ & 28 & & \\
\hline
\end{tabular}


The results of the study showed that the relative importance of the fixed and variable costs of garlic production, that the fixed costs represent about $30.2 \%$ of the costs of producing fed. of ripe garlic, amounting to 21.712 pounds / feddan, and the fixed costs are represented in the rent, which represents about $29.5 \%$ of the total costs and taxes represent $0.7 \%$.

As for the relative importance of the variable costs items, which represent about $69.8 \%$ of production costs, at the forefront comes the labor costs, which represent about $19.7 \%$ of the total costs, followed by the fertilizer costs, which represent about $13.9 \%$ of production costs, and then in the third order comes Seed costs, which represent about $9.4 \%$ of the total costs. Then cames the costs of municipal fertilizers, pesticides, fertilizers, irrigation, transportation and weight, which amounted to about $7 \%, 6.3 \%, 4.8 \%$, and $3.8 \%$, respectively.

By reviewing the data which shows the relative importance of the average fixed and variable cost items for manufacturing dried tons in garlic manufacturing companies in the sample of the study during the 2018/2019 season, it was found that the wages of workers represent the most important items of fixed costs, with an average of about 3000 pounds, representing about $55.4 \%$ of the average The total fixed costs, which amount to about 5415 pounds, and represent about $9.6 \%$ of the average total costs, which amount to about 31.385 pounds, then the costs of depreciation and improving product quality come in second place in terms of relative importance, as the average of each of them is estimated at about 500 pounds, representing about $9.2 \%$ of the average The total fixed costs, and about $1.6 \%$ of the average total costs, followed in order by the costs of renting machines, equipment and maintenance, where each of them amounted to about 450 pounds, 400 pounds, representing about $8.3 \%, 7.4 \%$ of the average total fixed costs during the study period, and about $1.3 \%$, $1.4 \%$ of the average total costs, respectively.

As for the variable costs, which include each of the raw materials (mature dry plasticized garlic), natural gas, electricity, water, packaging materials, and shipping freight, it was found from the same previous table that the costs of the main raw materials are ranked first in terms of relative importance For both variable costs and total costs alike, where the average ton in the factories of the study sample was estimated at about 19.650 pounds, representing about $75.7 \%$ of the average total variable costs, which amounted to about 25.970 pounds, and it represents about $62.6 \%$ of the average total costs, which amounted to about 31.385 pounds. Natural gas costs come in second place in terms of the relative importance of the items of variable costs and total costs alike, as the average ton amounted to about 3860 pounds, representing about $14.9 \%$ of the average total variable costs, and about $12.31 \%$ of the average total costs per ton (Table 11).

Data in Table (12) shows that the total yield per fed of ripe garlic that is sold in the local market during the garlic harvest season amounted to about 32,400 pounds/fed., where the average year of production per fed. of ripe garlic in the study sample 2018/2019 was about 10.8 tons/fed., the average price per ton during the season was about 3000 EGP, an acre of garlic achieved a net return of about $10,688 \mathrm{EGP} / \mathrm{fed}$ which is the difference between the total return per fed., which amounted to about 32,400 EGP, and the total costs, which amounted to about 21,712 EGP / fed. to the total costs amounted to about 1.49 pounds / fed., and this ratio is considered one of the important criteria for measuring economic efficiency to judge the production activity, and the increase of this percentage from the correct one indicates the profitability 
of the productive activity, and the return on the investment pound in the production of an acre of garlic was about 0.49 .

In the same time, the total revenue from exporting a ton of immature garlic has reached about 40,000 pounds / ton, where the results of the study showed that a ton of unripe garlic was exported at about 2500 US dollars. And that the net return amounted to about 19885 pounds / ton. And that the total return to the total costs amounted to about 1.99 pounds / ton, and this ratio is considered one of the important criteria for measuring the economic efficiency to judge the production activity, and the increase of this percentage from the correct one indicates the profitability of the productive activity, and the return on the investment in the preparation and export of tons of immature garlic has reached About 0.99 and the added value, which was estimated at 24000 pounds / ton.

\section{References}

Abbas Zaki Othman, lectures on garlic production and marketing in Egypt, Agricultural Research Center, Horticultural Research Institute.

Dalia Abdel Hamid Yassin and others, An analytical study of the losses in some stages of the value chain of the tomato crop, a case study of the Nubaria region, 27th Conference of Agricultural Economists 6-7 November ,2019 pp. 171: 190.

Danq Seven, Industrial Production Models.
Atherortical Study, New York, Springerver-Lage, 1966.

Gamal Siam, Value Chain Modernization Policies for the Vegetable Sector in Egypt Case Study of the Tomato Value Chain, 27th Conference of Agricultural Economists 6-7 November 2019 p. 1: 16.

Hani Naguib Elias, Lectures in Marketing, Agricultural Economics Research Institute, 2002.

Jaber Ahmed Bassiouni and Hanan Abdel Moneim Mohamed Zahran, Analysis of the Competitiveness of garlic Crop in the Most Important International Markets, Menoufia J. Agric. Economic \& Social Sci. Vol. 3, October, 2018, 489-504.

Ministry of Agriculture and Land Reclamation - Economic Affairs Sector - Agricultural Economics Bulletin, various issues.

Muhammad Salah El-Din El-Gendy and others, An economic study to analyze the value chain and marketing windows for the export of potatoes to the Russian Federation. Twenty-seventh Conference of Agricultural Economists November 67, 2019 p. 107: 128.

Wafaa Abdel-Karim Mohamed, An economic study of Egyptian garlic exports in foreign markets, The Egyptian Journal of Agricultural Economics, Volume Twenty-first, Issue Two, June 2011.

World Trade Organization https://comtrade.un.org/.

Zainab Omar OmarMahgoub, Benefit and Cost Analysis of Field Crops in Sharkia Governorate, Ph.D. thesis, Faculty of Agriculture, Zagazig University 2016.

\section{How to cite this article:}

Mohamed Hussien Mohamed Attwa, Hussien Mohamed Ahmed Hussien, Mohamed Desouki Hassan Dewdar and Ghada Abd El Samee Rabee Mansour Ghedan. 2021. Analytical Study of the Value Chains of Garlic Crop and the Role of Agricultural Manufacturing in Beni Suef Governorate, Egypt. Int.J.Curr.Microbiol.App.Sci. 10(12): 509-520.

doi: https://doi.org/10.20546/ijcmas.2021.1012.056 